\title{
KOSMOLOGIA I RZECZYWISTOŚĆ
}

Jedno z najbardziej podstawowych zagadnień filozofii nauki można ująć w pytaniu: czy teorie naukowe mówią o rzeczywistości? Od Kanta datuje się zmaganie nowożytnej filozofii z problemem stosunku ludzkiego poznania do rzeczywistości. Pytanie postawione w pierwszym zdaniu jest pewną wersją problemu Kanta: ludzkie poznanie zostało w nim zastąpione produktem ludzkiego poznania, a mianowicie naukową teorią, ale reszta pozostała $\mathrm{w}$ zasadzie bez zmian. Trzeba niejako wyjść poza naukową teorię, sięgnąć do rzeczywistości i rozstrzygnąć, czy to, co teoria mówi, jest zgodne z rzeczywistością, czy nie, względnie w jakim stopniu. Problem — wydawałoby się — równie beznadziejny jak w przypadku prób, by uchwycić kantowskie „ignotum X” i porównać je $\mathrm{z}$ własnymi treściami poznawczymi.

I właśnie dlatego, że zagadnienie wydaje się beznadziejne, nie brakło dążeń, by je zneutralizować. Stąd twierdzenia, że teorie są bądź tylko uporządkowaniem doznań zmysłowych, bądź specyficznym językiem, bądź - w taki czy inny sposób rozumianą - konstrukcją uczonych, nie pozostającą w żadnym bezpośrednim stosunku do tak zwanej rzeczywistości. Tego rodzaju twierdzenia często rodzily się jako opozycja przeciwko instynktownemu traktowaniu teorii naukowych jako wiernych (lub co najwyżej lekko tylko stylizowanych) kopii rzeczywistości. Naiwny realizm został odziedziczony przez nowożytne nauki w spadku po przednaukowych dociekaniach, które z reguły realistycznie traktują byty powoływane przez siebie do istnienia celem wyjaśnienia doznawanego świata. Ale nowożytne teorie naukowe bardzo szybko zerwały z tym zdroworozsądkowym poglądem i przybrały bardziej wyrafinowany stosunek do tego, co same głosiły. Już Newton nalegał na swoich czytelnikọ́w, by sił przyciągania, o jakich mówi jego teoria, nie uważali za „przyczyny zjawisk”, lecz za „siły matematyczne”, czyli za opis matematyczny czegoś, czego prawdziwej natury jeszcze nie znamy ${ }^{1}$.

Na temat stosunku teorii naukowych do rzeczywistości wylano morze atramentu. Jeżeli podejmuję ten temat, to tylko dlatego, że bez niego moje dociekania na temat „filozofii kosmologii”"2 byłyby niepełne. Nie mam również złu-

${ }^{1}$ Obszerniej na ten temat pisałem w artykule: Matematyka i wyobraźnia w teorii grawitacji (w druku: „Roczniki Filozoficzne KUL” 1988)

2 Por. moje artykuły: On the Cosmological Problem, „Acta Cosmologica” 14:1986 s. 57-72; Big Bang on Ultimate Questions (w: Origin and Early History of the Universe, Liège 1986, s. 411431;) Graniczny charakter kosmologii, „Tarnowskie Studia Teologiczne” 10:1987 s. 81-95. 
dzeń, że zdołam w tej dziedzinie powiedzieć coś istotnie nowego. Pragnę jedynie poruszyć zespół zagadnień dotyczących realizmu poznawczego w kontekście kosmologii, gdyż - jak sądzę — konfrontacja niektórych stanowisk epistemologicznych z praktyką badawczą w kosmologii może okazać się przynajmniej interesująca. Wobec ogromnego wachlarza możliwości moje podejście musi być selektywne. Najpierw poświęcę nieco uwagi fenomenalizmowi, gdyż był to historycznie pierwszy kierunek, zwiastujący zerwanie $\mathrm{z}$ naiwnym realizmem. Potem skoncentruję moje rozważania na tzw. naukowym realizmie, który jest bliskim mi stanowiskiem. Ponieważ jednak i tu rozrzut opinii jest znaczny, ułatwię sobie pracę, ograniczając się do realizmu w wydaniu Ernana Mc Mullina. Będzie to niejako materiał do własnej refleksji i do zastosowania ogólnofilozoficznych analiz do sytuacji badawczej panującej w kosmologii.

\section{MINIMALIZM POZNAWCZY I KOSMOLOGIA}

Z końcem XVI wieku istniały co najmniej cztery, rywalizujące ze sobą, „systemy świata": system Eudoksosa z kryształowymi sferami, obracającymi się koncentrycznie wokół Ziemi, system Ptolemeusza z deferentami i epicyklami, system Kopernika, poprawiony potem istotnie przez Keplera, i system Tychona de Brache. Ostatni tym różnił się od kopernikowskiego, że kazał krążyć Słońcu dookoła Ziemi, a wszystkim innym planetom dookoła Słońca ${ }^{3}$. Ponieważ podówczas wszystkie te systemy miały mniej więcej takie same kłopoty $\mathrm{z}$ uzgodnieniem swoich przewidywań z wynikami obserwacji astronomicznych, powstało pytanie o ich, jak mówiono, prawdziwość. Po prosecie Galileusza, gdy wokół tego pytania narosło wiele pozanaukowych emocji, sytuacja stała się jeszcze bardziej delikatna. Już w roku 1591 Patricius wyraził pogląd, że należy trzymać się wyników obserwacji a nie dociekać „prawdziwych” ruchów planet. W swojej Pancosmii pytał on: „Jaki jest więc w istocie nasz świat?” i odpowiadał sam sobie: „Wierz swoim oczom... Nie mówią ci one niczego o sferach, więc sfery nie istnieją"4. Jak wiadomo, znacznie wcześniej Osjander w napisanym przez siebie wstępie do De Revolutionibus Kopernika zastosował taką samą taktykę. Jego słowa mogłyby zostać wypowiedziane przez każdego szanującego się późniejszego pozytywistę: , „[...] nie jest koniecznym — pisał — by hipotezy były prawdziwe, ani nawet, by były prawdopodobne; jedna tylko rzecz wystarcza - by prowadzily do rachunku zgodnego z obserwacjami ${ }^{5}$.

W ten sposób powstał fenomenalizm, stanowisko głoszące, że wiedza na-

${ }^{3}$ Obszerniej na temat tych systemów por.: J. Dobrzycki, Astronomia przedkopernikowska, Toruń 1971, s. 35-42; A. G. P a ch olczy k, The Catastrophic Universe, Tucson 1984, s. 1128.

${ }^{4}$ Cytuję za: R. Harré, The Philosophies of Science, London 1985, s. 69. Autor ten zwrócil moją uwagę na związek pomiędzy kosmologią a początkami fenomenalizmu (por. rozdzial 3. cytowanej książki).

5 Tamże, s. 88. 
ukowa ogranicza się tylko do „tego, co widać”, natomiast wszelkie jej twierdzenia na temat czy to „istot rzeczy”, czy ,wewnętrznej struktury rzeczy” należy uznać co najwyżej za użyteczne fikcje. Wszystkie te twierdzenia późniejszego fenomenalizmu wypowiedział już Berkeley w swojej krytyce mechaniki Newtona. Naukowe zasługi Newtona nie stanowiły przedmiotu krytyki Berkeleya. Problem zaczynał się, gdy mechanikę traktowano jako ,naturalną filozofię”. „Prawa przyciągania i odpychania - pisal Berkeley — winno uważać się za prawa ruchu, a te $\mathrm{z}$ kolei za reguły lub metody zaobserwowane w trakcie produkowania przez nie naturalnych skutków. Przyczyny sprawcze i celowe tych skutów leżą poza obszarem rozważań mechanicznych. [...] Mechaniczne prawa przyrody czyli ruchu wskazują nam, jak działać i uczą, czego oczekiwać"6. Berkeleyowi, mimo całej jego filozoficznej szczerości, niewątpliwie przyświecały cele apologetyczne: pragnął on zneutralizować zgubne, jego zdaniem, skutki „filozofii mechanicznej” dla religii chrześcijańskiej, tymczasem na długo przed Machem ustalił podstawowe reguły pozytywistycznej interpretacji nauki?

Taktyka Berkeleya często (do dziś) bywa używana w obronie poglądu, głoszącego, że najgłębsza wiedza polega na znajomości istot rzeczy. Do istot tych — tak głosi się najczęściej — prowadzi tzw. intuicja intelektualna, będąca specyficzną metodą dociekań filozoficznych. Fenomenalizm wyznacza granice metodzie empirycznej: nauki doświadczalne dotyczą tylko zjawisk, filozofia może wnikać w istoty rzeczy ${ }^{8}$.

Pewną radykalizacją fenomenalizmu jest instrumentalizm. Radykalizacją - ponieważ o ile fenomenalizm ograniczył poznawczą rolę teorii naukowych do ujmowania tylko zjawisk, o tyle instrumentalizm w ogóle odmówił teoriom empirycznym funkcji poznawczych. Teorie takie - zdaniem instrumentalistów - nie dają „,wglądu w świat”, lecz stanowią jedynie narzędzie do organizowania badań; nie mogą więc być ani prawdziwe, ani fałszywe, ale tylko bardziej lub mniej skuteczne. Za poprzednika takiego poglądu można uważać Gassendiego, który już w 1658 roku w swoim dziele Syntagma twierdził, że hipotezy naukowe winny być traktowane jako ,naturalne narzędzia”, dzięki którym wiedza może zostać lepiej uporządkowana i stać się bardziej dociekliwa9 ${ }^{9}$. W praktyce granica między instrumentalizmem i fenomenalizmem zaciera się

${ }^{6}$ Siris III [w:] The Works of George Berkeley, ed. A. C. Fr a se r, London 1901, s. 231-233. Obszerniej na temat fenomenalizmu Berkeleya por.: R. Harré, jw., s. 70-72; D.J. Raine, M. Hell e r, The Science of Space-Time, Tucson 1981, s. 42-46.

${ }^{7} \mathrm{~K}$. Popper wyróżnił 21 tez w pismach Berkeleya, które uprzedzają późniejsze twierdzenia Macha, a także innych pomachowskich filozofów nauki; - K. Popper, A Note on Berkeley as Precursor of Mach and Einstein, [w:] Conjectures and Refutations, New York... 1968, s. 166-174.

${ }^{8}$ Por. M. H ell e r, Spór między esencjalizmem a fenomenalizmem w kontekście nauk empirycznych, „Analecta Cracoviensia” 13:1981 s. 9-16. Ostrą krytykę esencjalizmu przeprowadził Popper: Three Views concerning Human Knowledge, [w:] Conjectures and Refutations..., s. 97-119.

${ }^{9}$ R. Harré, jw., s. 88. 
i jeden $\mathrm{z}$ tych dwu kierunków nierzadko korzysta $\mathrm{z}$ argumentów przytaczanych na rzecz drugiego. Instrumentalistyczna koncepcja nauki stała się przedmiotem ostrej krytyki ze strony Poppera ${ }^{10}$.

Fenomenalizm i instrumentalizm doprowadziły do pozytywistycznej koncepcji nauki i same, w pewnej mierze, stały się jej częścią. Ale w pewnej mierze tylko, gdyż, włączając się w strumień myśli pozytywistycznej, uległy kolejnej radykalizacji. Fenomenalizm przestal być metodologicznym rozgraniczeniem pomiędzy istotami, którymi ma się zajmować filozofia, i zjawiskami, pozostającymi domeną nauk przyrodniczych; stał się tezą głoszącą, że samo rozróżnienie na istoty i zjawiska jest bezsensowne: istnieje tylko to, co można obserwować $^{11}$. Instrumentalizm pojął narzędną funkcję praw przyrody jako służenie tylko jednemu celowi - ekonomicznemu opisowi danych empirycznych. „W przyrodzie nie ma prawa ugięcia - pisał Mach, do którego tak chętnie odwoływali się neopozytywiści wiedeńscy - lecz tylko odrębne przypadki ugięcia. Prawo ugięcia jest zwartą, skrótową regułą, wymyśloną przez nas w celu myślowego zrekonstruowania jakiegoś faktu [ugięcia]"12.

Nie miejsce tu na szczegółowe przedstawianie i poddawanie analizie neopozytywistycznych poglądów na naukę ${ }^{13}$. Chcąc jednak umieścić epistemologiczne rozważania w kontekście nauki o Wszechświecie, warto zwrócić uwagę na filozoficzną atmosferę, w jakiej rozwijała się młoda kosmologia relatywistyczna. Pierwsza kosmologiczna praca Einsteina ukazała się w roku 1917; lata dwudzieste były okresem pionierskich badań de Sittera, Friedmana, Lemaître'a; w latach trzydziestych paradygmat kosmologiczny wyraźnie okrzepł i stawiał przed sobą coraz odważniejsze problemy ${ }^{14}$. Równolegle coraz bardziej wzmagały się wpływy neopozytywistycznej wizji nauki i bynajmniej nie ograniczały się one jedynie do kręgów zawodowych filozofów nauki. Wystarczy uświadomić sobie, że dokładnie w tym okresie fizycy, pracujący w dziedzinie mechaniki kwantowej, w przeważającej liczbie pozwolili narzucić sobie kopenhaską interpretacją tej fizycznej teorii - interpretację, w której nawet niewprawny metodolog z łatwością dostrzeże wyraźne znamię neopozytywistycznych poglądów. Fizycy-relatywiści, być może idąc za przykładem Einsteina, okazali się bardziej odporni na wpływy pochodzące od filozofów z Wiednia.

10 Tamże, s. $107-114$.

$11 \mathrm{O}$ tzw. regule fenomenalizmu zob.: L. Koł a kow s ki, Filozofia pozytywistyczna, Warszawa 1966 , s. $11-13$.

12 E. Mach, The Science of Mechanics, La Salle 1974, s. 582. Trzeba jednak przyznać, że neopozytywiści odczytali myśl Macha zbyt jednostronnie. Kilka stron dalej bowiem pisał on (s. 587): „Funkcją nauki, tak jak ją dziś pojmujemy, jest zastąpienie doświadczenia. A więc, z jednej strony nauka musi pozostawać w obszarze doświadczenia, ale $\mathrm{z}$ drugiej strony musi wybiegać poza nie, nieustannie oczekując potwierdzenia lub obalenia. Tym, co nie dopuszcza ani potwierdzenia, ani obalenia, nauka przestaje się interesować. Nauka działa i to działa wyłącznie w obszarze ni edo k oń czo n e go doświadczenia” (podkreślenie Macha).

13 Uczyniłem to w swoich książkach: Spotkania z naukq, Kraków 1974, (głównie roz. 9); Wszechświat i Stowo, Kraków 1981, (roz. 5).

14 Por. moją książkę: Ewolucja kosmosu i kosmologii, Warszawa 1985, oraz: O. Godart, M. Helle r, Cosmology of Lemaître, Tucson 1985. 
Jak wyglądałaby dziś kosmologia relatywistyczna, gdyby wówczas poddała się „,neopozytywistycznej redukcji”? Ogólna teoria względności mogła wylegitymować się wtedy jedynie trzema tzw. klasycznymi testami obserwacyjnymi, które sprowadzały się $\mathrm{w}$ gruncie rzeczy do niewielkich numerycznych poprawek do praw Newtona. I to dwa spośród tych trzech testów daje się wyprowadzić z zasady równoważności bez pomocy równań pola ogólnej teorii względności. W tej sytuacji trudno byłoby traktować teorię Einsteina jako ekonomiczny opis faktów: fakty były co najwyżej trzy a ogólna teoria względności stanowiła wielką strukturę matematyczną, w swojej architekturze porównywalną tylko z ówczesną mechaniką kwantową.

W kosmologii relatywistycznej sytuacja wyglądała jeszcze bardziej zniechęcająco. Wprawdzie Lemaître już w roku 1927 porównał jeden z modeli kosmologicznych z wynikami pomiarów przesunięć ku czerwieni i pokazał, że wyniki te nie przeczą modelowi ${ }^{15}$, ale z pewnością taka „weryfikacja” nie zadowoliłaby żadnego $\mathrm{z}$ neopozytywistycznych filozofów nauki. W publikacjach kosmologicznych tamtych czasów powoływano się jeszcze na inne testy kosmologiczne $^{16}$, ale wszystkie one mogły zostać przeprowadzone tylko „w zasadzie” i wszelkie próby ich rzeczywistego wykonania dawały zupełnie nierozstrzygające wyniki.

Po roku 1965 (odkrycie kwazarów i promieniowania tła ${ }^{17}$ ) sytuacja uległa drastycznej poprawie. Standardowy model kosmologiczny uważa się dziś za „dobrze potwierdzony danymi obserwacyjnymi”18. Co to jednak znaczy „dobrze potwierdzony"? Nawet dość pobieżna analiza pokazuje, że idzie tu: po pierwsze, o niesprzeczność danych obserwacyjnych z przewidywaniami modelu; po drugie, o „pasowanie" do tego modelu danych obserwacyjnych, które bezpośrednio z niego nie wynikają; i po trzecie, o funkcje usługowe, jakie model spełnia w stosunku do innych teorii fizyki i astronomii (tak np. astronomia „potrzebuje” kosmologii do interpretacji obserwacji kwazarów a fizyka do wielkiej unifikacji oddziaływań). Wydaje się, że właśnie te „funkcje usługowe" odegrały szczególnie doniosłą rolę w „ustandaryzowaniu się" modelu. Można by tu nawet mówić o pewnego rodzaju kryterium jedności fizyki: kosmologia przestała być marginesowym dodatkiem do innych teorii fizycznych; sama stała się teorią fizyczną, bez której inne teorie nie mogłyby funkcjonować tak jak funkcjonują.

Gdy jednak zastosować jakiekolwiek bardziej rygorystyczne kryteria do obecnie możliwych do przeprowadzenia zabiegów testujących modele kosmo-

${ }^{15}$ Por. M. Helle r, Ewolucja kosmosu i kosmologii..., s. 68-72; O. Godart, M. Helle r, jw., s. $51-65$.

16 Przeglądowy artykul w tej kwestii napisal: H. P. Robertson, Relativistic Cosmology, „Review of Modern Physics” $5: 1933$ s. 62-90.

${ }^{17}$ Zob. M. Helle r, Ewolucja kosmosu i kosmologii..., s. 158-179.

18 Confrontation of Cosmological Theories with Observational Data, ed. M. Lo n a i r,Dordrecht-Boston 1974. 
logiczne, natychmiast okazuje się, że zabiegi te wymagają wielu empirycznie nieweryfikowalnych założeń ${ }^{19}$ i faktycznie testują znacznie mniej niż się powszechnie sądzi ${ }^{20}$. Sprawa znacznie pogarsza się, gdy zamiast standardowego modelu kosmologicznego wziąć pod uwagę scenariusze proponowane do procesów rozgrywających się w bardzo wczesnym Wszechświecie. Sytuacja przypomina tu stan kosmologii (dla późnego Wszechświata) w latach międzywojennych, tzn. całkowitą dominację hipotez nad danymi empirycznymi i możliwość sprawdzania jedynie „w zasadzie”. Mimo tych wszystkich „metodologicznych niedostatków", kosmologia relatywistyczna lat siedemdziesiątych i osiemdziesiątych stała się organiczną częścią współczesnej fizyki. Jeżeli pojawiają się co do tego głosy protestu, to nie tylko są one nieliczne, ale na ogół nie walczą ze standardową kosmologią jako obecnym narzędziem badania świata, lecz wyrażają przekonanie o tymczasowości tego narzędzia ${ }^{21}$.

\section{KRYTYKA FENOMENALIZMU}

Filozofowie nauki często podkreślają, że, podobnie jak fizycy i astronomowie upraszczają i stylizują badaną przez siebie rzeczywistość, i oni mają prawo w ten sam sposób traktować naukę, która przecież stanowi przedmiot ich badań. Ale jeżeli tak, to - podobnie jak przyroda jest w stanie sfalsyfikować przynajmniej niektóre teorie przyrodnicze ${ }^{22}$ — faktyczny rozwój nauki jest w stanie poddać falsyfikacji przynajmniej niektóre twierdzenia metodologów. Sądzę, że tego rodzaju falsyfikacja nastąpiła w stosunku do fenomenalistycznej koncepcji nauki. Zanim jednak przejdę do uzasadnienia tego poglądu, winienem uściślić, co rozumiem przez „fenomenalistyczną koncepcję nauki”.

Z tego, co powyżej powiedziano, można wydobyć następujące twierdzenia:

1. Teorie naukowe ograniczają się jedynie do zjawisk (fenomenów), czyli do tego, co można stwierdzić bezpośrednim poznaniem zmysłowym, natomiast wszelkie ich stwierdzenia dotyczące „wewnętrznej struktury rzeczy” (lub istoty) należy uznać co najwyżej za użyteczne fikcje (teza fenomenalizmu).

1a. Samo rozróżnienie pomiędzy zjawiskami a „wewnętrzną strukturą rzeczy" jest pozbawione sensu (teza pozytywizmu).

2. Teorie naukowe w ogóle nie spełniają funkcji poznawczych, lecz są jedynie narzędziem do organizowania badań (teza instrumentalizmu).

${ }^{19}$ Por.: G. F. R. Ellis, Cosmology and Verifiability, „The Quaterly Journal of the Royal Astronomical Society" 16:1975 s. 245-264; tenże, Relativistic Cosmology. Its Nature, Aims and Problems, [w:] General Relativity and Gravitation, ed. B. B e r to t ti, F. de Felice, A. Pas coli in i, Dordrecht-Boston 1984, s. 215-288.

${ }^{20}$ G. F. R. Ellis, S. D. Nel [...], Ideal Observational Cosmology „Physics Reports” 124:1985 s. $315-417$

${ }_{21}$ Por. A. G. Pacholczyk, jw.

${ }^{22}$ Mimo całej debaty nad kryterium falsyfikacji, jest rzeczą niewątpliwą, że pewne teorie naukowe zostały faktycznie sfalsyfikowane, np. naiwna teoria samorództwa lub sztucznych kanałów na Marsie. 
2a. Narzędna funkcja teorii naukowych sprowadza się wyłącznie do ekonomicznego opisu wyników wielu doświadczeń (teza Macha).

Tezy (1) - (2a) będę nazywać fenomenalistyczna koncepcją nauki. Nie pretenduję tu do metodologicznej ścisłości; moje definicje mają jedynie roboczy charakter. Dokładne opracowanie przedstawionych tu myśli wymagałoby obszernego studium metodologiczno-historycznego. Twierdzę zatem, że fenomenalistyczna koncepcja nauki została sfalsyfikowana przez rozwój dwudziestowiecznej kosmologii relatywistycznej.

I tak, nie jest prawdą, że współczesne teorie naukowe, a wśród nich kosmologia, nie rozróżniają pomiędzy stroną zjawiskową, w pewnym sensie przypadkową, a stroną istotną, czyli wewnętrzną strukturą rzeczy (teza 1a), choć rozróżnienie pomiędzy tymi dwoma aspektami jest inne niż sądzili zwolennicy tradycyjnego fenomenalizmu. Teorie współczesnej fizyki są strukturami formalnymi, a w takiej strukturze stosunkowo łatwo można określić, jakie jej elementy są istotne, a jakie przypadkowe. Tak na przykład w strukturze matematycznej zwanej grupą, która służy do modelowania wielu sytuacji fizycznych, tzw. działanie grupowe i jego własności, wyrażone w aksjomatach grupowych, należą do istoty tej struktury, natomiast charakter elementów tworzących grupę (np. to czy są to liczby rzeczywiste, macierze, czy jeszcze coś innego) jest zupełnie nieistotny dla pojęcia abstrakcyjnej grupy.

W świetle powyższych uwag staje się rzeczą oczywistą, że współczesne teorie naukowe (a wśród nich i kosmologia relatywistyczna) mówią przede wszystkim o elementach istotnych struktur, przy pomocy których modelują fizyczną rzeczywistość. Tak na przykład w standardowym modelu kosmologicznym (modelu Friedmana-Lemaître'a) metryka Robertsona-Walkera jest niewątpliwie istotnym elementem struktury formalnej, jaką model ten przypisuje światu, podczas gdy wybór współrzędnych, w których ta metryka jest wyrażana, jest przypadkowym elementem struktury. A zatem również tezę 1 . fenomenalistycznej koncepcji nauki należy uznać za nieprawdziwą.

Nie można wątpić $w$ to, że struktury formalne są potężnym narzędziem współczesnych teorii empirycznych. Bez ich udziału dane empiryczne byłyby nie tyle „bezładnym zbiorem nieodczytanych informacji” (jak powszechnie się utrzymuje), lecz — przynajmniej w przypadku bardziej wyrafinowanych działów współczesnej fizyki - w ogóle nie mogłyby istnieć. Odpowiednio zinterpretowane struktury formalne, wskazują jak konstruować przyrząd, co mierzyć i jak rozumieć wyniki pomiarów. Już samo zinterpretowanie danych pomiarowych jest pewną poznawczą funkcją teorii, ale tylko pewne elementy struktury danej teorii można uważać za wejścia, poprzez które przyjmuje ona wyniki doświadczeń. Wejścia te nie wyczerpują całej struktury. Co więcej, tylko w całości struktury wejścia empiryczne nabierają znaczenia. Przez utożsamienie struktury formalnej danej teorii z fragmentem rzeczywistości otrzymujemy jej strukturę. Na tym polega mechanizm rozumienia świata stosowany 
przez najbardziej zaawansowane teorie współczesnej fizyki. Tą metodą uzyskaliśmy wgląd do wnętrza atomu, tą metodą staramy się zrozumieć strukturę oddziaływań subatomowych.

Rozpatrzmy przykład z kosmologii. Znajomość składowych tensora metrycznego (metryki Robertsona-Walkera) w standardowym modelu kosmologicznym jest niezbędna do wyliczenia testów obserwacyjnych, wynikających z modelu. Jednakże funkcje metryki bynajmniej nie wyczerpują się w tym zadaniu. Metryka informuje nas również (a bardziej teoretycznie nastawieni kosmologowie byliby skłonni powiedzieć: informuje nas przede wszystkim) o pewnych ważnych strukturalnych cechach Wszechświata, a mianowicie o tym, że we Wszechświecie istnieje uniwersalny czas kosmologiczny i że jest sens mówić o zbiorach zdarzeń zaszłych (równocześnie) w pewnej chwili tego czasu, czyli o przestrzeniach chwilowych. Kosmologowie nie traktują tej informacji jako użytecznej fikcji, lecz jako informację o strukturze Wszechświata, choć oczywiście doskonale zdają sobie sprawę ż tego, że nie należy tej informacji traktować dosłownie, ale tylko jako „dobre przybliżenie”.

W sensie powyższych uwag sądzę, że teza 2 . fenomenalistycznej koncepcji nauki jest nie do utrzymania. W konsekwencji to samo dotyczy tezy (2a). Można by nawet powiedzieć, że standardowy model kosmologiczny nie jest specjaInie ekonomicznym opisem wyników obserwacji. Jak wiadomo, danych obserwacyjnych o znaczeniu kosmologicznym jest stosunkowo niewiele (a przed rokiem 1965 było ich bardzo niewiele) i powoływanie się na ogromny aparat teoretyczny ogólnej teorii względności, kosmologii relatywistycznej i wielu innych teorii fizycznych, bez pomocy których kosmologia byłaby bezsilna, w celu „spójnego opisu” tych danych, trudno uznać za przejaw zmysłu myślowej oszczędności. Sens wyrażenia „wewnętrzna struktura rzeczy”, występującego w powyższym argumencie, jest oczywiście odmienny od rozumienia ,istoty” przez klasyczny fenomenalizm. W niczym to jednak nie narusza wniosku, że fenomenalistycznej koncepcji nauki nie da się utrzymać: niezależnie od rozumienia „istoty” czy „wewnętrznej struktury” nie jest prawdą, że teorie naukowe ograniczają się tylko do tego, co da się bezpośrednio zaobserwować.

$\mathrm{Na}$ zakończenie tej części analiz zapytajmy, dlaczego kosmologia relatywistyczna okazała się nieposłuszna wytycznym z Wiednia i nie dała się zamknąć w fenomenalistycznej koncepcji nauki. Myślę, że odpowiedź - przynajmniej w części - jest następująca. Neopozytywiści wiedeńscy usiłowali zrozumieć rewolucję, jaka dokonała się w nauce na początku stulecia. Tymczasem rewolucja ta nie była jeszcze zakończona. Osięgnięcia ogólnej teorii względności i kosmologii relatywistycznej miały stać się dalszym ciągiem przewrotu. Uczestnicy Koła Wiedeńskiego zastali w nauce pewną „sytuację problemową" i poddali ją wnikliwej — choć niekiedy jednostronnej - analizie metodologicznej. Nie mogli wówczas wiedzieć, że sytuacja problemowa nie jest jeszcze zamknięta, że zajdą w niej zmiany, które inaczej rozłożą istotne akcen- 
ty i ukażą odmienne oblicze nauki od tego, jakie wydawało się kształtować na początku lat trzydziestych. Błędem neopozytywistów było traktowanie pewnego etapu rozwoju nauki za jej ostatnie słowo ${ }^{23}$.

\section{REALIZM NAUKOWY}

Z krytyki fenomenalistycznej koncepcji nauki wyłania się pozytywny obraz: Teorie naukowe przynoszą pewne, choć na ogół tylko przybliżone, informacje o świecie. Informacje te odsłaniają strukturę, o której mamy prawo przypuszczać, że jest, w jakimś sensie, podobna do rzeczywistej struktury świata. Tego rodzaju obraz wymaga głębszego wyjaśnienia i uzasadnienia. Okazuje się, że zadanie to w dużej mierze już zostało wykonane. Realistyczne interpretacje nauki przybierają ostatnio na sile ${ }^{24}$. Wystarczy zatem dokonać krytycznego przeglądu argumentów przytaczanych na rzecz poglądu realistycznego i zbadać jak one funkcjonują na terenie kosmologii. Pierwszą część tego zadania ułatwię sobie, ograniczając się do uważnej lektury artykułu Ernana McMullina $^{25}$, który przekonywająco - jak sądzę - uzasadnił stanowisko zwane przez tego autora naukowym realizmem. Stanowisko to nie usiłuje narzucać nauce obcych jej duchowi reguł metodologicznych, lecz stara się pozostawać w zgodzie z rzeczywistą praktyką naukową. Zastosowanie argumentów McMullina do kosmologii (po niezbędnych retuszach) odłożę do następnego paragrafu. Dodatkowym uzasadnieniem trafności wyboru pracy McMullina jest pozytywny odzew, jaki wywołała ona w świecie filozofów nauki ${ }^{26}$. McMullin zaznacza, że przymiotnik „naukowy”, w określeniu: „naukowy realizm”, nie ma na celu przypisywać realizmowi rangi twierdzenia naukowego. Jest to oczywiście twierdzenie filozoficzne, a odnosi się ono tylko do teorii naukowych, co właśnie podkreśla nazwa. Oto teza McMullina:

Podstawowym roszczeniem naukowego realizmu [...] jest twierdzenie, że długofalowy sukces naukowej teorii daje podstawę do wierzenia, że coś takiego jak byty i struktury postulowane przez daną teorię rzeczywiście istnieją. W twierdzenie to wbudowane są cztery ważne kwalifikacje: (1) teoria winna odnosić sukcesy w ciągu znacząco długiego okresu; (2) sukces teorii w wyjaśnianiu stanowi pewną rację, choć nie zniewalającą, by w tę teorię wierzyć; (3) wiara w teorię jest wiarą w to, że teoretyczne struktury są czymś podobnym do struktur w rzeczywistości; (4) nie głosi się niczego na temat jakiejś specjalnej, czy bardziej podstawowej, czy uprzywilejowanej formy istnienia bytów postulowanych ${ }^{27}$.

${ }^{23} \mathrm{Na}$ temat istotności i nieistotności we współczesnych teoriach naukowych piszę obszerniej w artykule: Spór między esencjalizmem a fenomenalizmem $w$ kontekście nauk empirycznych, „Analecta Cracoviensia” 13:1981 s. 9-16.

${ }^{24}$ Por.: Scientific Realism, ed. J. Le plin, Berkeley 1984; w dziele tym jedynie trzy artykuły bronią stanowiska antyrealistycznego.

${ }^{25}$ E. Mc Mulli in, A Case for Scientific Realism, tamże, s. 8- 40.

${ }^{26}$ Zob.: A. P. Pe a cock e, Intimations of Reality, Notre Dame 1984. Zasadniczą tezę swej książki oparł autor na pracy McMullina, o której była mowa wyżej.

${ }^{27}$ E. McMullin, jw., s. 26. 
„Sprawę na rzecz naukowego realizmu” (the case for scientific realism) McMullin łączy z silnym naciskiem na strukturalny typ wyjaśniania, funkcjonujący w naukach empirycznych. Jego zdaniem, w ciągu ostatnich dwustu lat na terenie tych nauk miało miejsce "postępujące odkrywanie struktur". McMullin wyjaśnia: „naukowcy konstruują teorie, które tłumaczą obserwowane własności fizycznego świata przez postulowanie modeli ukrytych struktur bytów podlegających badaniu. Zakłada się, że tego rodzaju struktura uzasadnia przyczynowo obserwowalne zjawiska, a teoretyczny model przybliża zjawiska, z których czerpie swoją moc wyjaśniającą ${ }^{28}$. Autor ilustruje swoją tezę licznymi przykładami z geologii i biologii. Naukowcy obdarzają dużym zaufaniem wyjaśniania strukturalne. I to nie tylko wtedy, gdy idzie o skuteczność w czynieniu empirycznych przewidywań, lecz także gdy idzie o sam model jako odkrywaj ą cy pewną strukturę.

Wyjaśnianie strukturalne z jednej strony odznacza się płod ności ą w tłumaczeniu znanych już danych obserwacyjnych i w przewidywaniu nowych, ale, z drugiej strony, także pewną ot wa r tości ią czy twórczości ą: odkrywane struktury okazują się na tyle plastyczne, że bardzo często niejako dostosowują się do anomalii doświadczalnych, jakie w tym czasie mogą się pojawić, a niekiedy same podpowiadają następny krok w teoretycznych dociekaniach. Co więcej, proces odkrywania struktur, mimo ich częstych modyfikacji, a czasem daleko idących ulepszeń, jest procesem o znacznej ciągłości. Ciągłość ta okazuje się następstwem wyżej wspomnianej otwartości modeli: struktury odkrywane przez teorie fizyki czy chemii wydają się podlegać ewolucji w kierunku struktur o coraz większej mocy wyjaśniającej. Uwaga ta (udokumentowana przez McMullina przykładami z nauk empirycznych) w znacznej mierze neutralizuje zarzuty przeciwko naukowemu realizmowi, płynące ze strony kuhnowskiej koncepcji nauki jako nieciągłego procesu historycznego. Wydaje się, że nie ma jakiejś apriorycznej racji, dlaczego strukturalne wyjaśnianie miałoby być aż tak skuteczne. Najlepszym — i zarazem najprostszym — wytłumaczeniem tego faktu jest zgodzenie się, że modele teoretyczne wystarczająco dobrze przybliżają strukturę rzeczywistego świata, która odpowiada przyczynowo za obserwowane zjawiska" 29 .

Należy tu uczynić ważną uwagę. W sławnym sporze Einsteina z Bohrem twórcę teorii względności uważa się za realistę, ponieważ — w przeciwieństwie do Bohra - wierzył on w deterministyczne zachowanie obiektów kwantowych. Owszem, jak wiadomo z biografii Einsteina, był on realistą, gdyż utrzymywał, że nauka opisuje obiektywną rzeczywistość, ale w sporze z Bohrem

${ }^{28}$ Tamże, s. $26 \mathrm{n}$.

${ }^{29}$ Wyjaśnieniu strukturalnemu McMullin poświęcił artykuł: Structural Explanation, „American Philosophical Quaterly” 15:1978 s. 139-147. Czytamy tam (s. 145): „Zrozumienie, jakie ono [wyjaśnianie hipotetyczno-strukturalne] dostarcza, nie sprowadza się do trafnych przewidywań i technicznej kontroli; jest ono otwarciem dotychczas ukrytego świata procesów i struktur zarówno makroskopowych, jak i mikroskopowych". 
głosił on coś więcej niż realizm; głosił mianowicie, że świat mikrofizyki jest ostatecznie deterministyczny. Obecny stan fizyki wskazuje na to, iż w tym ostatnim twierdzeniu Einstein był w błędzie. Nie przeczy to jednak realistycznemu stanowisku. Po prostu rzeczywistość świata, choć inna niż wierzył Einstein, jest nadal obiektywna i nadal ujawnia swoje struktury teoriom współczesnej fizyki.

\section{STRUKTURALNE WIDZENIE RZECZYWISTOSCI}

Jasno sformułujmy tezę wynikającą $\mathrm{z}$ analiz przeprowadzonych przez McMullina. Naukowy realizm nie oznacza założenia, że obiekty mikroświata (i analogicznie megaświata) istnieją tak samo jak obiekty makroskopowe, ani nawet, że obiekty mikroświata (np. elektrony lub kwarki) w ogóle istnieją. Teza naukowego realizmu stwierdza jedynie, że istnieje coś, co zasługuje na miano „obiektywnej rzeczywistości” i że teorie współczesnej nauki trafnie tę rzeczywistość przybliżają. Ale stwierdzenie, że rzeczywistość składa się z obiektów nie jest częścią tezy naukowego realizmu. Co więcej nawet, jak widzieliśmy w poprzednich rozważaniach, teza naukowego realizmu dość wyraźnie wiąże się z postulatem wyjaśniania strukturalnego, a to sugerowałoby, że rzeczywistości należy raczej przypisać status struktury niż status zbioru obiektów. Nie wykluczone, że obiekty to tylko nasz sposób ujmowania pewnych fragmentarycznych aspektów struktury.

Jeszcze raz pragnę podkreślić, że strukturalistyczny obraz świata, jaki wyłania się z osiągnięć współczesnej fizyki, jest wynikiem jej konsekwentnie rozumianej matematyzacji. Paul Roman podjął ten wątek we wstępie do swojego podręcznika fizyki matematycznej ${ }^{30}$. Za jedno $\mathrm{z}$ mott wybrał on powiedzenie J. Dieudonné: „Matematyka jest logicznym badaniem relacji pomiędzy pewnymi bytami, a nie badaniem natury tych bytów." Rozwijając tę myśl, Roman pisze:

Podstawowa rola matematyki w ludzkiej myśli naukowej jest zdumiewająca, a nawet prowadząca do nieporozumień. Można tu osiągnąć częściowe zrozumienie, jeżeli weźmie się pod uwagę cele i zamiary nowoczesnych matematyków. Wydaje się, że - zgodnie z ich poglądem - pierwszorzędnym celem matematyki jest badanie struktur. To nastawienie, które rozwinęło się w ciągu ostatnich pięćdziesięciu lub siedemdziesięciu lat, radykalnie różni się od nastawienia klasycznej matematyki. Klasyczna matematyka w swojej istocie była 'konstruktywistyczna'. W celu udowodnienia, że obiekt (funkcja, liczba itp. spełniająca pewne warunki) istnieje, uważano za konieczne podać procedurę skonstruowania tego obiektu. Natomiast przedmioty nowoczesnej matematyki są abstrakcyjnymi symbolami, zidentyfikowanymi tylko przez „opis”. Takie przedmioty lączy się w pewne grupy i bada się relacje, jakie pomiędzy nimi zachodzą. Prawda o danej relacji jest zagwarantowana przez reguty,

${ }^{30} \mathrm{P}$. R o m a n, Some Modern Mathematics for Physicists and Other Outsiders, t. 1, Oxford 1975, s. XXIII-XXV. 
które wymagają zbadania jedynie ksztattu (formy) odpowiednich związków pomiędzy obiektami ${ }^{31}$.

Wypowiedź tę należy rozumieć w świetle motta zaczerpniętego do Dieudonné: natura obiektów nie stanowi przedmiotu zainteresowań matematyki, całą swoją uwagę skupia ona na relacjach. Ponieważ zaś, jeżeli coś matematykę nie interesuje (matematykę a nie matematyków), to to coś dla ma te mat y k i nie istnieje. Tę samą myśl można wypowiedzieć jeszcze inaczej: n a t u rę obiektów matematycznych stanowią wyłącznie relacje, w jakie obiekty te wchodzą ze swoim kontekstem. To właśnie mamy na myśli, stwierdzając, że współczesna matematyka bada struktury (tzn. sieć relacji), a nie obiekty. Uwagi te - jak słusznie zauważa Roman — „mogą przyczynić się do zrozumienia ścisłych związków, jakie zachodzą pomiędzy badaniem praw przyrody a funkcjonowaniem nowoczesnej matematyki. Zarówno nauki przyrodnicze, jak i matematyka, sprowadzają się ostatecznie do badania struktur" 32 . Teorie fizyczne są po prostu strukturami matematycznymi zinterpretowanymi jako struktury świata ${ }^{33}$.

„Strukturalne widzenie rzeczywistości” w kosmologii relatywistycznej funkcjonuje dokładnie tak samo, jak w innych działach fizyki teoretycznej. Poszczególne rozwiązania równań Einsteina (z „kosmologicznymi” warunkami brzegowymi, czyli tzw. modele Wszechświata) są pewnymi strukturami matematycznymi. Przy badaniu rozwiązań tradycyjnymi metodami lokalnymi strukturalny charakter rozwiązań łatwo uchodził uwadze. Rozwiązanie redukowało się w zasadzie do pewnego wyrażenia matematycznego, a jego badanie polegało na ujawnianiu rozmaitych własności tego wyrażenia. Współczesne metody globalne badania rozwiązań są strukturalne w samej swej istocie. Stosując je mamy bezpośrednio do czynienia ze strukturą (którą można wizualnie przedstawić, na przykład za pomocą diagramów Penrose'a), a wyrażenia matematyczne, jakimi się operuje, są tylko pewną postacią zakodowania tej struktury $^{34}$.

A więc modele kosmologiczne są pewnymi strukturami. Jednakże realizm naukowy nie wymaga, by strukturę modelu, potwierdzanego przez obserwacje, dokładnie przypisywać światu. Realizm naukowy stwierdza jedynie, że długotrwałe sukcesy modelu kosmologicznego w wyjaśnianiu danych empirycznych, świadczą o tym, że struktura świata jest pod pewnymi względami podobna do struktury modelu. A jeżeli mielibyśmy do czynienia nie z sukcesami jednego modelu, lecz ciągu modeli, wyjaśniających coraz lepiej i coraz to nowe dane empiryczne, to - na mocy realizmu naukowego - mamy prawo sądzić,

${ }^{31}$ Tamże, t. 1 s. XXIV.

${ }^{32}$ Tamże.

${ }^{33}$ Por. wyżej przypis 1.

${ }^{34}$ Obszerniej o metodach globalnych współczesnej kosmologii piszę w: On the Cosmological Problem, ,Acta Cosmologica” 14:1986 s. 57-72. 
że struktury tych modeli coraz lepiej przybliżają strukturę świata.

Pod jakim względem, i w jakim stopniu, struktura świata jest podobna do struktury modeli kosmologicznych? Tego oczywiście nie możemy wiedzieć, gdyż struktura świata jest nam dostępna jedynie za pośrednictwem struktury modeli kosmologicznych. Można tylko sądzić, choćby na podstawie dotychczasowej historii nauki, że struktura świata jest niepomiernie bardziej skomplikowana od jakichkolwiek dostępnych nam struktur matematycznych. Ale sukcesy nauki, rozumiane w duchu naukowego realizmu, pozwalają wnosić, że struktura świata odznacza się tą niezwykle dla nas przychylną cechą, że można ją przybliżać dostępnymi dla nas, prostymi strukturami matematycznymi..Sądzę, że struktury matematyczne, za pomocą których modelujemy rzeczywistość, swoją prostotą tak bardzo odbiegają od bogactwa struktury rzeczywistego świata, że zamiast o podobieństwie powinniśmy raczej mówić o pewnego rodzaju rezonansie. Konstruowane przez nas struktury wpadają niejako w rezonans ze strukturą świata w ten sposób, że mimo swojego drastycznego uproszczenia informują nas o pewnych strukturalnych cechach te go, co jest.

Równania Einsteina są oczywiście także pewną strukturą matematyczną. I to strukturą znacznie bardziej skomplikowaną niż którekolwiek ze znanych nam ich rozwiązań. Wystarczy uświadomić sobie, że równania Einsteina, rozpisane bez żadnych upraszczających założeń, zawierałyby około dziesięciu tysięcy członów. Każdy, kto zetknął się z równaniami różniczkowymi o pochodnych cząsteczkowych, wie co to oznacza. Natomiast znane nam rozwiązania, którymi z takim powodzeniem modelujemy różne sytuacje fizyczne (łącznie z Wszechświatem w wielkiej skali) są rozwiązaniami równań Einsteina uproszczonych do kilku, niekiedy, kilkunastu, członów. A bogactwo struktur, jakie te rozwiązania przedstawiają, jest i tak ogromne. Zaledwie w kilku wypadkach zdołaliśmy te struktury rozszyfrować do końca. Być może równania znacznie lepiej przybliżają strukturę rzeczywistości niż znane nam ich rozwiązania.

Jak należy rozumieć ostatnie zdanie? Równania są pewnym zespołem warunków (zespół ten także stanowi matematyczną strukturę), jakie muszą spełniać struktury, które uważamy za modele świata. Znajomość tego rodzaju warunków, wraz z tzw. warunkami brzegowymi, w zasadzie jednoznacznie wyznacza strukturę modelu (rozwiązania). Niestety, na ogół tylko w przypadku znacznie uproszczonych warunków, wyrażonych równaniem, i dla szczególnie prostych warunków brzegowych, potrafimy odnaleźć wyznaczone przez nie rozwiązanie.

Podobna sytuacja ma miejsce także w przypadku innych równań fizyki matematycznej. Parafrazując powiedzenie Maxwella, równania są mądrzejsze niż znane nam ich rozwiązania. Znane rozwiązania są zwykle gorszym przybliżeniem struktury świata niż na to zezwalałaby pełna struktura równań. Rozwiązania, które by znacznie lepiej przybliżały strukturę świata, są zwykle bardzo trudne do znalezienia, choć często mamy podstawy sądzić, że istnieją. Na przy- 
kład, standardowy model kosmologiczny stanowi niezwykle proste rozwiązanie równań Einsteina z mocno je upraszczającymi symetriami Robertsona- -Walkera. Dzięki tym symetriom standardowy model jest grubym, choć pracującym całkiem dobrze, przybliżeniem struktury świata. Wiemy jak rozluźnić upraszczające założenia i przejść do rozwiązań z mniejszymi symetriami, np. do modeli typu Bianchiego, tzn. przestrzennie jednorodnych, choć niekoniecznie izotropowych. Zdajemy sobie sprawę z tego, że model dokładniej przybliżający rzeczywistość musi być także przestrzennie niejednorodny (przecież niejednorodności materii w postaci galaktyk i gwiazd na pewno istnieją); wiemy, że w zbiorze rozwiązań równań Einsteina istnieje „dużo” rozwiązań przestrzennie niejednorodnych, ale znamy ich zaledwie kilka i to, znowu, tak prostych, że są one „fizycznie nierealistyczne”, czyli bardzo odległe od rzeczywistej struktury świata.

Rodzi się pytanie: a może równania fizyki (przynajmniej niektóre) dokładnie opisują strukturę świata, a tylko my, z konieczności, znajdujemy szczególnie proste rozwiązania, a więc rozwiązania jedynie w grubym przybliżeniu zgodne z rzeczywistością? Odpowiedź na to pytanie jest negatywna. Swiadczą o tym kontrprzykłady. Równania teorii grawitacji Newtona modelowały pole grawitacyjne mniej dokładnie niż czynią to obecnie równania Einsteina. Wiemy także, że i te ostatnie są tylko pewnym przybliżeniem. Nie zdają one bowiem sprawy $\mathrm{z}$ kwantowej natury pola grawitacyjnego, podczas gdy pole to w niektórych sytuacjach z pewnością posiada również aspekt kwantowy. Jesteśmy skazani - czy to na poziomie równań, czy ich rozwiązań - tylko na zbliżanie się do struktury, jaką je st Wszechświat ${ }^{35}$.

Największym sukcesem nauk empirycznych — sukcesem trwającym od początku czasów nowożytnych do dziś - jest coraz lepsze ugruntowywanie się przekonania, że Wszechświat stopniowo, choć tylko w przybliżeniu, ujawnia nam tajemnice swojej struktury.

\section{COSMOLOGY AND REALITY}

\section{Sum mary}

Developments in relativistic cosmology falsify both phenomenalistic and instrumental conceptions of science. Many examples taken from the twentieth century cosmology show that the role of cosmological models cannot be limited neither to observable phenomena nor to organizing experi-

${ }^{35}$ Niektóre swoje poglądy na ten temat obszerniej przedstawiłem w pracy: Ontologiczne zaangażowania wspótczesnej fizyki, „Analecta Cracoviensia” 18:1986 s. 4-20. 
mental data. Theories of modern physics, relativistic cosmology among others, give an insight into the structure of the world. Long chain of successes in predicting and explaining phenomena by mathematical theories of modern science allows one to believe that mathematical structures, which constitute the essence of these theories, approximate the structure of the world. Modern mathematical methods, commonly used in cosmology, clearly reveal the structural character of the science of the Universe. 